\title{
Temperature and Gasifying Media Effects on Chicken Manure
}

\section{Pyrolysis and Gasification}

\author{
M. S. Hussein ${ }^{1}$, K. G. Burra ${ }^{2}$, R. S. Amano ${ }^{3}$ and A. K. Gupta ${ }^{4}$ \\ Department of Mechanical Engineering \\ University of Maryland \\ College Park, MD 20742, USA
}

\begin{abstract}
Continuous increase in chicken meat consumption calls for the chicken industry for unpreceded dense chicken production and associated waste production. The chicken farms produce large amounts of chicken manure that can no longer be directly used as a fertilizer due to concerns of land pollution and water bodies eutrophication. The gasification of chicken manure can convert the negative economic value chicken manure into fuel to help foster energy security and energy sustainability. The pyrolysis and gasification of chicken manure was studied using different gasifying media and temperatures ranging between $600-1000{ }^{\circ} \mathrm{C}$ in $100{ }^{\circ} \mathrm{C}$ temperature steps. The evolved gases were analyzed using gas

${ }^{1}$ Graduate Student, University of Wisconsin, Milwaukee, WI, USA

${ }^{2}$ Graduate Student, University of Maryland, College Park, MD, USA

${ }^{3}$ Professor, University of Wisconsin, Milwaukee, WI, USA

${ }^{4}$ Distinguished University Professor. Email: akgupta@ umd.edu, Phone: 301.405.5276

Keywords: Steam and $\mathrm{CO}_{2}$ gasification, chicken manure, biomass, evolved syngas analysis, renewable energy, pyrolysis and air gasification
\end{abstract}


chromatography and the results are presented in this paper. Gasification with carbon dioxide and steam were found to give the highest energy yield in the form of syngas; air gasification required the least time and is thus expected to have a better financial feasibility. While air gasification provided highest carbon conversion with low syngas energy yield, at higher temperatures steam and carbon dioxide gasification yielded similar conversion to air gasification but with high syngas energy yield. At higher temperatures, gaseous yields were higher due to the tar cracking and further reformation to provide enhanced carbon conversion. The reduction in tar was more favorable at high temperatures. Tar is known to increase the maintenance time and costs, but its reduction comes at the cost of increased energy input.

\section{Introduction}

The average chicken consumption continues to increase annually, and in the USA alone 12 billion pound of dry chicken manure is produced every year [1]. This production exceeds the soil absorption limits if the manure is used as a fertilizer, resulting in environmental issues [2]. In the state of Maryland, chicken manure was attributed to high concentration of phosphorous (60\% higher than the levels required for plant growth) found in the soil thus making phosphorous a soil pollutant [2]. The localized traditional fertilizer applications of chicken manure is no longer an option as such wastes can be managed by transporting and reforming into usable energy [3]. Thermochemical 
conversion techniques such as pyrolysis and gasification can convert the chicken manure into syngas, which can be further processed to fuels or directly used for power, and thus help reduce the dependence on fossil fuels. When the waste decomposes in the landfills, it emits methane into the atmosphere which is a greenhouse gas and some environmental activists blame agriculture manure for the global warming that can amount to the extent of fossil fuel burning [4]. Converting the manure will decrease greenhouse gases produced and generate energy in a nearly carbon neutral process [5]. Direct combustion of manure is inefficient compared to pyrolysis and gasification. Due to high moisture and ash content, manure has very low heating value in its solid state compared to gas/liquid products of gasification. The higher heating value of syngas allows a more stable, more efficient, and energy denser combustion and thus more efficient energy production. Products of gasification are also easily used in the currently available infrastructure for power generation and transportation. Thermochemical conversion methods such as gasification and pyrolysis are industrially viable options with high throughput compared to bio-chemical conversion methods such as anaerobic digestion due to the high thermochemical reaction rates.

Thermochemical decomposition of solid biowaste starts with the decomposition of the complex and polymeric organic chains, followed by reforming of these products in the presence of the gasifying agent such as steam, air, or $\mathrm{CO}_{2}$ to produce product gas that is characterized by a higher heating value than the solid biowaste. The major components of product gas are $\mathrm{H}_{2}, \mathrm{CO}, \mathrm{CO}_{2}, \mathrm{CH}_{4}, \mathrm{C}_{2} \mathrm{H}_{6}, \mathrm{C}_{2} \mathrm{H}_{4}, \mathrm{C}_{2} \mathrm{H}_{2}$, and other higher series of hydrocarbons. Undesirable byproducts containing a mixture of heavy aromatic hydrocarbon residues, referred to as tar, are also formed from the escaping of the 
secondary reforming of cracked polymers which must be further pyrolyzed or reformed to enhance the syngas yield. The fraction of mass converted to tar is highly dependent on the heating rate, gasification media and the reactor temperature. The syngas composition is affected by the gasifying agent, temperature, feedstock composition and other reactor operational parameters under non-catalytic reaction conditions. Compositional homogeneity of the fuel produced from hetereogeneous sources including chicken manure, poultry litter, biomass, solid wastes, and coal makes gasification an attractive solution with feed flexibility compared to direct combustion of these low-value heterogeneous feedstocks. Considerable studies have been carried out on biomass gasification on the catalytic effects, and thermochemical parameters such as temperature, heating rate, gasifier type and feedstock [5-20]. Equations (1-5) show the major representative governing reactions (considering $\mathrm{C}$ to represent the biomass) that occur during gasification.

Char-Oxidation: $\quad \mathrm{C}+\mathrm{O}_{2} \Rightarrow \mathrm{CO}_{2}$

Boudouard reaction: $\quad \mathrm{CO}_{2}+\mathrm{C} \rightleftharpoons 2 \mathrm{CO}$

Water gas shift reaction:

$$
\mathrm{CO}+\mathrm{H}_{2} \mathrm{O} \rightleftharpoons \mathrm{CO}_{2}+\mathrm{H}_{2}
$$

Water gas reaction:

$$
\mathrm{C}+\mathrm{H}_{2} \mathrm{O} \rightleftharpoons \mathrm{CO}+\mathrm{H}_{2}
$$

Thermal cracking:

$$
\mathrm{C}_{\mathrm{n}} \mathrm{H}_{\mathrm{m}} \Rightarrow \mathrm{C}^{*}+\mathrm{C}_{\mathrm{x}} \mathrm{H}_{\mathrm{y}}+\mathrm{H}_{2}
$$

Chicken manure is a heterogeneous mixture of chicken droppings, waste beddings, waste food, and feathers from the coops. Chicken manure is characterized by high nitrogen, phosphorus and ash content which makes it a lower grade feed compared to conventional biomass such as wood. These differences in the constituents of chicken 
litter from other bio wastes motivates for investigations into the decomposition behavior of chicken litter [21]. Thermogravimetric analysis (TGA) highlighted one of the differences from other bio-wastes and coal. It was found that manure starts decomposition at lower temperatures with maximum weight loss rate observed at $370{ }^{\circ} \mathrm{C}$ [22]. TGA also showed a more complicated pyrolysis of chicken manure with three stages of weight loss, unlike woodchips pyrolysis, which occurs in two stages because of lignocellulose content. Cellulose and hemicellulose decomposition, lignin decomposition and residual char devolatilization were found to be the three stages of chicken litter decomposition. Higher manure content in the waste litter assisted in faster decomposition. Higher syngas yields at the expense of decreased liquid and char yields were obtained at higher temperatures [23]. The decarboxylation of minerals carbonates present in chicken manure ash resulted in an increase in $\mathrm{CO}_{2}$ yields at temperatures above $700{ }^{\circ} \mathrm{C}$ and stabilize for temperature above $1000{ }^{\circ} \mathrm{C}$ [22]. Decomposition of protein content in chicken litter into hydrocarbons was proposed the reason for highly viscous, acidic bio-oils produced from chicken litter with heating values higher than conventional hardwood derived bio-oils [24].

High ash content constituting one-fifth of the chicken litter by weight conventionally helped in fertilizing applications. But due to large production of chicken litter, the dangers of leaching and eutrophication limits them from being used as fertilizers in traditional methods. So, phosphorous and potassium oxides as ash contents can make it an efficient fertilizer after gasification [25]. However, the issue facing gasification concerns low ash-fusion temperatures experienced due to high $\mathrm{Ca}, \mathrm{Na}$, and $\mathrm{K}$ components, all of which are present in chicken wastes. Unstable inorganic content 
interfering with gasification by decarboxylation of carbonates and the low melting points of its constituents makes it essential to consider their kinetic and physical characteristics into gasification models to be operable at high temperatures, unlike the conventional models which consider the ash content to be inert [26].

Co-gasification of chicken litter and coal was successfully demonstrated, but with no change in product gas heat content [27]. Almost equal contents of carbon and oxygen in chicken manure can theoretically make it a self-sufficient feedstock with no need of additional gasifying agent and such method was called "auto-gasification" [28]. But the same investigation also found limited carbon availability for reacting with oxygen due to inhibiting effects from the presence of other hydrocarbon and water gas reaction causing oxidation of evolved $\mathrm{CO}$ to form $\mathrm{CO}_{2}$. High syngas yields rich in $\mathrm{H}_{2}$ were also obtained from steam gasification of chicken manure by catalytic enhancement using $\mathrm{Ni}-\mathrm{Al}_{2} \mathrm{O}_{3}$ as the catalyst in fluidized bed reactors at $600{ }^{\circ} \mathrm{C}$ [29]. Other unconventional gasifying techniques such as super-critical gasification were also investigated using chicken litter [30,31]. Investigative techniques used to understand biomass gasification are abundantly available in the literature, which can provide pathway into understanding the kinetics and feasibility of chicken manure as fuel production feedstock as well as the effect of gasifying parameters.

High quality syngas with high hydrogen content can be obtained using steam gasification but with a drawback of high endothermicity and long residence times [3234]. Use of oxygen/air is efficient in reducing reaction times and auto-thermal capability, but the need for gas separation for improved quality of syngas is expensive. Use of carbon dioxide as gasifying agent is also feasible which can help in reusing hot exhaust 
emissions, but the operable temperatures are the highest due to Boudouard reaction equilibrium. Comparative study on the effect of gasifying agent is essential to understand kinetics of litter gasification and help optimize the gasification process according to downstream application for better efficiency and economy. Comparison of steam and $\mathrm{CO}_{2}$ on woodchips char and grapefruit skin char gasification $[35,36]$, pyrolysis and steam on paper gasification [37] in lab scale and demonstrative studies to examine the effect of gasifying medium were carried out in the past on different types of biomass. Such lab scale studies [37] provide quantified results on the effects of gasifying agent, temperature and feedstock on the product gases that helps in the design and selection of the gasifying conditions necessary for large-scale gasifier operations. However, such studies on the gasification of chicken manure have been limited. Although TGA and STA studies on the decomposition of chicken manure in $\mathrm{CO}_{2}, \mathrm{~N}_{2}$, and air were investigated [38], the need for product gas analysis is essential to provide enhanced understanding of such research.

This present paper investigates isothermal gasification of chicken manure at temperatures ranging from 600 to $1000{ }^{\circ} \mathrm{C}$ using different gasifying media (nitrogen, air, carbon dioxide, or steam) in a laboratory scale semi-batch reactor. The evolved gas was analyzed using gas chromatography with specific focus on the evolution of product gas yield and composition. The effects of the gasifying conditions on the product gas composition is expected to help understand the kinetics of chicken manure gasification in broader perspective and also help to optimize the commercial gasifier conditions for efficient and economical operation. 


\section{Experimental}

\subsection{Reactor Facility}

The experimental facility, designed and built at the Combustion Laboratory, University of Maryland, was used in the analysis of gas products from gasification of various kinds of wastes [37,39-42]. Figure 1 shows a schematic diagram of the semibatch lab scale reactor setup. A constant flow rate of $\mathrm{N}_{2}$ was used for all of the experiments as a tracer gas. Pyrolysis tests used only $\mathrm{N}_{2}$ as gasifying agent to maintain non-oxidizing environment. However, in gasification, the corresponding gasifying agent gases were mixed with $\mathrm{N}_{2}$ and preheated to reaction temperature in an electric furnace before reacting with the solid waste sample. An $\mathrm{H}_{2} / \mathrm{O}_{2}$ flame was used to generate the steam used in steam gasification, which was later mixed with $\mathrm{N}_{2}$ downstream of the flame and then conditioned (as $\mathrm{N}_{2}$ addition and heat losses lowered the temperature of products of $\mathrm{H}_{2} / \mathrm{O}_{2}$ flame) in electric furnace to maintain the required reaction temperatures. The $\mathrm{H}_{2} / \mathrm{O}_{2}$ ratio was adjusted such that no concentrations of $\mathrm{H}_{2}$ or $\mathrm{O}_{2}$ were detected by the gas chromatograph which means complete and stoichiometric combustion of $\mathrm{H}_{2}$ and $\mathrm{O}_{2}$ was established. The mixing section was then connected to a steel tube mounted inside two stages of electric tube furnaces. The first stage was a preheat section to ensure that the feed gases achieved the required temperature before interacting with the bio waste sample. The second section equipped with electric furnace maintained at required temperature was the gasifier, where the solid waste sample was introduced. Quantified mass of the chicken manure was first loaded into a quartz tube (in an inert sample holder) which was then inserted into the reactor tube inside the furnace after a 
steady state condition of temperature and gasifying agent flow rates was achieved. The electric heaters were PID controlled and capable of maintaining temperature up to 1200 ${ }^{\mathrm{o}} \mathrm{C}$.

The steel reactor tube was connected to a quick connect elbow at the end of the heating section. The elbow was then connected to a flexible stainless steel pipe which, in turn, delivered the gas products to a 3 stage condensation unit. The condensation unit consisted of vented chamber and two glass beakers. All of the three elements of the condensation unit were submerged in an ice bath. In the venting chamber, most of the gas was vented to the exhaust while a smaller portion of the product gas passed through the two other stages of condensation prior to the gas analysis. The gases were driven by a positive displacement pump through a gas dryer to dry the product gas before it entered the gas analyzer (Micro gas chromatograph). The gas chromatograph was capable of completing an analysis in 3 minutes. So, gas samples were stored in the gas sampling bottles during the first 5 minutes at each minute intervals after which they were analyzed continuously every 3 minutes using the gas chromatograph. After the completion of each test, the gas samples collected for the first five minutes were analyzed using the gas chromatograph.

Micro gas chromatography analyzer was calibrated against standard gas mixtures, and the combined accuracy of the gas analysis was $\pm 0.1 \%$. The mass flow rates of individual components were further computed using the known $\mathrm{N}_{2}$ flow rate. The dry gas volume concentrations from the gas chromatography analysis were used to find the flow rate of other gases. Mass flow rate of gases were quantified using $\mathrm{N}_{2}$ as inert tracer gas at a known flow rate and using mass conservation of $\mathrm{N}_{2}$. Volumetric content of each species 
were divided by that of nitrogen followed my multiplying the fraction with the input nitrogen volumetric flow rate and standard density of analyzed species [37].

\subsection{Operating conditions}

Chicken manure used in the present investigation was $35 \mathrm{~g}$ of dried chicken manure fertilizer sample of irregular granular form with sizes ranging from 1-3 mm and apparent

density of $1.5 \mathrm{~g} \cdot \mathrm{ml}^{-1}$ (obtained from particle immersion in fluid). These particles were filled in the quartz tube with a packing density of $0.7 \mathrm{~g} \cdot \mathrm{ml}^{-1}$. The ultimate and proximate analysis along with the higher heating value (HHV) [43] of the sample is given in Table 1. Tracer gas flow of 0.09 mol. $\mathrm{min}^{-1}$ of $\mathrm{N}_{2}$ was used for all the experiments reported here at temperatures of $600,700,800,900$, and $1000^{\circ} \mathrm{C}$. For air gasification, $\mathrm{O}_{2}$ was added to obtain a net concentration of gasifying agent similar to air (21\%). While for carbon dioxide or steam gasification, the flow rate was calculated so that the number of oxygen atoms would be the same, provided hydrogen gas used for steam generation was 0.19 mol.min ${ }^{-1}$. Four different gases $\left(\mathrm{N}_{2}, \mathrm{Air}, \mathrm{H}_{2} \mathrm{O}\right.$, and $\left.\mathrm{CO}_{2}\right)$ in ascending order of oxygen content of $0, .023, .095$, and $.095 \mathrm{~mol} . \mathrm{min}^{-1}$ respectively at five different temperatures were studied.

\section{Results and discussion}

Gas chromatography provided an accurate mole fraction on dry basis of detectable gases including $\mathrm{N}_{2}$ which was introduced at known flow rate. Using the mole fractions and the known $\mathrm{N}_{2}$ flow rate, the volumetric flow rate of other gases can be 
calculated. The volumetric flow rate was then multiplied by the gas density to quantify the mass flow rate of individual components.

At high temperatures (above $1000{ }^{\circ} \mathrm{C}$ ), deposits were formed on the quartz tube near to the vicinity of the sample. The deposits formed were due to ash melting and it is highly recommended to increase the gasification temperature above $1000{ }^{\circ} \mathrm{C}$ to avoid fouling and mitigate downtime during continuous operation with operation in slagging mode to avoid the issues of deposition. Syngas may contain nitrogenous gas components in the form of $\mathrm{NH}_{3}, \mathrm{HCN}$, and $\mathrm{HNCO}$ and sulfurous components as $\mathrm{H}_{2} \mathrm{~S}$ and $\mathrm{SO}_{\mathrm{x}}$, and their precursors so that they must be removed. While these exist in low volumetric concentrations, they are not analyzed in this paper. They do not contribute any significant effect on the manure decomposition rates and product gas output and can be removed by wet scrubbing techniques, which are feasible and reliable for gasification.

\subsection{Evolution of Product gas flow-rate}

Figure 2(a-c) shows the evolution of tar-free dry molar concentration (without considering $\mathrm{N}_{2}$ and $\mathrm{O}_{2}$ ) of syngas using air, steam, $\mathrm{CO}_{2}$ as gasifying agents. Initial evolution for first 5 minutes corresponds to devolatilization, which produced different volatiles and further reforming and cracking of the evolved volatiles. Later part of this evolution corresponded to the gasification of remaining char, which reacted in a quasiequilibrium state and the product gas composition evolved according to the equilibrium reactions. For air gasification, the products in the later portion were $\mathrm{CO}$ and $\mathrm{CO}_{2}$ as

oxidation of char using $\mathrm{O}_{2}$ occurs by conversion to $\mathrm{CO}$ and further to $\mathrm{CO}_{2}$. For steam gasification, the later zone has high $\mathrm{H}_{2}$ evolution from steam-char gasification and water 
gas shift reaction. While for $\mathrm{CO}_{2}$ gasification, the primary syngas product is $\mathrm{CO}$, which was obtained from Boudouard reaction.

Figure 3(a-d) shows the evolutionary behavior of hydrogen mass flow rate for different gasification media at different temperatures, while Fig. 3(e) shows a comparison between different temperature for steam gasification. Higher flow rates of hydrogen evolved over longer periods of time using steam can be observed as compared to other gasifying agents. The higher $\mathrm{H}_{2}$ can be attributed to reactions in Eq. (3-5), while the longer peaks are attributed to the slow heterogeneous char-steam gasification, see Eq. (4). The peak of $\mathrm{H}_{2}$ evolution also tends to occur earlier when the temperature was increased due to the high heating rate (sample introduced at room temperature) and the high reaction rate which allowed more bonds to break resulting in more gaseous yields. Although the reactor was at isothermal condition, the solid sample introduced was initially at room temperature and it needed certain transition time to reach the reactor temperature. This heating time, a measure of heating rate, decreased with increase in final set temperature and was estimated to be 1 minute to reach $900{ }^{\circ} \mathrm{C}$ from the previous studies [39]. This can be justified by Fig. 3(e) where the peak at $1000{ }^{\circ} \mathrm{C}$ was 4 times that at $700{ }^{\circ} \mathrm{C}$. High tar production is undesirable as it tends to increase blockage in gas pipes thus increasing the maintenance costs and downtime apart from the loss of potential product syngas yield. When air was used the reaction completed in shorter periods especially at higher temperatures. A faster reaction is desirable as it decreases the biowaste resident time and the energy required to complete the reaction. Temperature is usually limited to $1000{ }^{\circ} \mathrm{C}$ to avoid ash melting which would in turn cause blockage due to agglomeration. The ash melting was observed in the form of an enamel like layer 
adhering to the quartz tube. The purpose of this paper was on quantifying the effect of operational conditions on the product gas yield from chicken manure gasification; the details of ash properties were not addressed.

The methane production from steam $\left(\mathrm{H}_{2} \mathrm{O}\right)$ gasification shown in Fig. 4(e) follows the same trend as hydrogen with majority of the gas produced during the early stages of pyrolysis. The increase in temperature promoted cracking of more hydrocarbons to increase in $\mathrm{CH}_{4}$ production. Increase in methane production with increase in temperature corresponds to thermal enhancement of heavy hydrocarbon cracking, see Eqn. (5), and increase in reaction rate of water gas reaction and Boudouard reaction, see Eqn. $(2,4)$, which increases consumption of $\mathrm{CO}_{2}$ and steam $\left(\mathrm{H}_{2} \mathrm{O}\right)$ by carbon formed from cracking. This decreases the net available reforming agents for methane to reform. This enhancement suggests that with increase in temperature, the $\mathrm{CH}_{4}$ consumption due to methane reforming reaction is less than the increase in $\mathrm{CH}_{4}$ production due to ring opening and cracking reactions of hydrocarbons. From Fig. 4(a-d), comparing methane evolution for different gasifying agents at different temperatures, methane production seems to benefit from the exothermic reactions in the presence of oxygen, the largest peak is present with air gasification except at $1000{ }^{\circ} \mathrm{C}$ where pyrolysis case $\left(\mathrm{N}_{2}\right)$ generated the largest methane peak. The relative drop of $\mathrm{CH}_{4}$ peak for air gasification at higher temperatures compared to pyrolysis is attributed to minimal effect on $\mathrm{CH}_{4}$ evolution beyond $900{ }^{\circ} \mathrm{C}$ using air, while for pyrolysis case it increased significantly due to lack of oxidizing environment along with increased cracking of heavy hydrocarbons to form methane and hydrogen. The evolution of heavier hydrocarbons was similar to methane with their peak flow rates decreasing as their molecular weight increased. 
Increase in the temperature, yielded lower flow rates of heavier hydrocarbons (enhanced cracking) and higher flow rates of hydrogen.

Higher mass flow rates of $\mathrm{CO}$ were produced when $\mathrm{CO}_{2}$ gas was used for gasification, see Fig. 4(a-d). The higher flow rates were observed at temperatures higher than $700{ }^{\circ} \mathrm{C}$ where Eq. (2) becomes more effective. The evolution of $\mathrm{CO}$ for the $\mathrm{CO}_{2}$ gasification is similar to $\mathrm{H}_{2}$ evolution during steam gasification in the stages after pyrolysis in terms of the time duration. This similarity corresponds to the slow reaction rate of both the heterogeneous reactions given by Eq. $(2,4)$ during dry and steam gasification of the residual char, respectively. At $600{ }^{\circ} \mathrm{C}$, all the gasifying agents produced similar amounts of $\mathrm{CO}$ because at this low temperature $\mathrm{CO}$ was the product of the breaking down of bonds (pyrolysis). A significant flow rate of $\mathrm{CO}$ was also produced when air was used due to the incomplete combustion of char and hydrocarbon. The flow rate of $\mathrm{CO}$ was 2 order of magnitudes higher than the flow rate of hydrogen especially in the case of $\mathrm{CO}_{2}$ assisted gasification. As with other components mentioned above, increase in temperature increased the flow rates of $\mathrm{CO}$ also. Significant effect of temperature can be observed in Fig. 5(e) for temperatures above $800{ }^{\circ} \mathrm{C}$ as the Boudouard reaction equilibrium favors $\mathrm{CO}$ over $\mathrm{CO}_{2}$ for such temperatures.

The total syngas flow rate obtained is shown in Fig. 6(a-e). Note that only the calibrated gases with calorific values $\left(\mathrm{H}_{2}, \mathrm{CO}, \mathrm{CH}_{4}, \mathrm{C}_{2} \mathrm{H}_{2}, \mathrm{C}_{2} \mathrm{H}_{4}, \mathrm{C}_{2} \mathrm{H}_{6}\right)$ were considered in this flow rate. The peaks of the flow rate when air was used in gasification were similar to pyrolysis but the reaction completed faster than other gas agents. $\mathrm{CO}_{2}$ gasification was the slowest amongst all gases and was mainly dependent on the $\mathrm{CO}$ yield. The syngas yields from steam gasification were lowest among the others as the gas 
yield in steam gasification was predominantly $\mathrm{CO}_{2}$, due to water gas shift reaction, which was not accounted here.

\subsection{Cumulative energy yield}

Figure 7 shows the energy conversion yield for the five different cases calculated from the summation of products of accumulative yield of product gas components and their corresponding lower heating values. The accumulative energy output for different gas media increased with the increase in temperature. At $600{ }^{\circ} \mathrm{C}$, the highest amounts of energy were generated in air gasification case. At this low temperature, the exothermic reaction due to the oxidation of some of the resulting gases, helps to increase in the conversion rate as this exothermic energy yield increases the available energy for endothermic reactions and thus increase their reaction rates. $\mathrm{CO}_{2}$ gasification generated the lowest energy yield at the $600{ }^{\circ} \mathrm{C}$ because Boudouard reaction was inactive at this low temperature. At $700{ }^{\circ} \mathrm{C}, \mathrm{CO}_{2}$ gasification was improved as Boudouard equilibrium drove forward and $\mathrm{CO}_{2}$ achieved the highest efficiency at this temperature. Air gasification did not improve at the same rate as the other cases due to the combustion of some of the product gases. Pyrolysis yielded lowest energy yield at $700{ }^{\circ} \mathrm{C} . \mathrm{CO}_{2}$ gasification maintained the highest except at $1000{ }^{\circ} \mathrm{C}$ when steam provided the highest energy generation. Energy yields from pyrolysis had a steady progression with temperature. Air had the slowest progression starting with highest yield at $600{ }^{\circ} \mathrm{C}$ and lowest yield at 1000 ${ }^{\circ} \mathrm{C}$. Energy yields from steam gasification increased rapidly with increase in temperature and generated the most energy at $1000{ }^{\circ} \mathrm{C}$, but produced yields lower than $\mathrm{CO}_{2}$ gasification at other temperatures. 


\subsection{Carbon conversion efficiency}

Carbon conversion efficiency was calculated as the ratio between the mass of carbon in the evolved gas to the total mass of carbon in the input chicken manure sample. For the case of $\mathrm{CO}_{2}$, the mass of carbon in $\mathrm{CO}_{2}$ in the gasifying agent was subtracted from the mass of carbon in the evolved gas. The carbon conversion efficiency can be used as an indication for the gas conversion (or cold gas) efficiency. High carbon conversion efficiency would mean more gas evolution, less tar generation, and less residual mass. Figure 8 shows carbon conversion efficiency obtained from the 4 different gasifying agents at 5 different temperatures. The general trend was an increase in the efficiency of conversion with increase in temperature due to high thermal stability of product gases compared to aromatic and cyclic hydrocarbons. At $600{ }^{\circ} \mathrm{C}$, the highest efficiency was for the air gasification case which was followed by increased efficiency of steam and $\mathrm{CO}_{2}$ gasification from $700{ }^{\circ} \mathrm{C}$ when steam achieved the highest carbon efficiency. $\mathrm{N}_{2}$ pyrolysis progressed steadily but was limited by the fixed carbon content in the manure which will not be gasified by pyrolysis. $\mathrm{CO}_{2}$ gasification had the lowest efficiency at $600{ }^{\circ} \mathrm{C}$ then the efficiency increased from $700{ }^{\circ} \mathrm{C}$. The low efficiency at 600 ${ }^{\circ} \mathrm{C}$ was because of high thermal stability of $\mathrm{CO}_{2}$ making it unlikely to react at this low temperature; it only acted as a heat sink slowing down the reaction as compared to $\mathrm{N}_{2}$ pyrolysis.

\section{Conclusions}


Chicken manure gasification and pyrolysis was studied using 4 different gasifying media (nitrogen, air, carbon dioxide, and steam) and at 5 different temperatures (600, $700,800,900$, and $\left.1000{ }^{\circ} \mathrm{C}\right)$. The energy yield increased with increase in temperature. The $\mathrm{CO}_{2}$ gasification produced the highest yield followed by steam gasification, pyrolysis and air gasification. Gasifier operation at temperatures below $750{ }^{\circ} \mathrm{C}$ was noted to be inefficient as the tar production increased as observed from the carbon conversion efficiency. The fusion deposition of ash layer on the sample holder discourages operation of gasifier at temperatures higher than $1000{ }^{\circ} \mathrm{C}$ to avoid ash fusion difficulties. Gasification reactions were fastest with air gasification, decreasing the reaction time by $75 \%$ when compared to $\mathrm{CO}_{2}$, at the expense of the total energy yield which was also decreased by $55 \%$ at $1000{ }^{\circ} \mathrm{C}$. Except for $\mathrm{N}_{2}$, which represents only pyrolysis, the total energy yield was inversely correlated to the total reaction time for different gases at the same temperature. At lower temperature air yielded energy comparable or superior to the other gases as the exothermic reactions provided more energy that helped in the cracking of bonds. High hydrogen yield can be obtained with steam gasification while $\mathrm{CO}_{2}$ gasification can recycle $\mathrm{CO}_{2}$ from exhausts, but both of these come with the challenge of endothermicity costs. This can be reduced by using air gasification which is energy efficient and fast, but yields in low quality/dilute product yield. The decision of choosing best gasifying agent depends on the available resources and the desired output. Case wise optimization is recommended prior to selecting the right gasifying agent. This study can guide in determining the most feasible gas for gasification depending on the source and availability of the gases, the energy costs, and the design temperature. 


\section{Acknowledgments}

This research was supported by the Office of Naval Research (ONR) and is gratefully acknowledged.

\section{References}

[1] "National Chicken Council" [Online]. Available:

http://www.nationalchickencouncil.org/about-the-industry/statistics/per-capitaconsumption-of-poultry-and-livestock-1965-to-estimated-2012-in-pounds/. [Accessed: 01Jul-2016].

[2] “The Agriculture Phosphorus Initiatve," 2016, [Online]. Available: http://mda.maryland.gov/Pages/PMT.aspx. [Accessed: 01-Jul-2016].

[3] Kelleher, B., Leahy, J., Henihan, A., O’Dwyer, T., Sutton, D., and Leahy, M., 2002, “Advances in poultry litter disposal technology - a review,” Bioresour. Technol., 83(1), pp. 27-36.

[4] "World Resource Institute" [Online]. Available: http://www.wri.org/blog/2014/05/everything-you-need-know-about-agriculturalemissions. [Accessed: 22-Aug-2016].

[5] Kumar, A., Jones, D. D., and Hanna, M. A., 2009, “Thermochemical Biomass Gasification: A Review of the Current Status of the Technology," Energies, 2(3), pp. 556581.

[6] Bahng, M.-K., Mukarakate, C., Robichaud, D. J., and Nimlos, M. R., 2009, “Current 
technologies for analysis of biomass thermochemical processing: a review.," Anal. Chim. Acta, 651(2), pp. 117-38.

[7] Kalinci, Y., Hepbasli, A., and Dincer, I., 2009, "Biomass-based hydrogen production: A review and analysis,” Int. J. Hydrogen Energy, 34(21), pp. 8799-8817.

[8] Woolcock, P. J., and Brown, R. C., 2013, “A review of cleaning technologies for biomassderived syngas," Biomass and Bioenergy, 52, pp. 54-84.

[9] Sutton, D., Kelleher, B., and Ross, J. R. H., 2001, "Review of literature on catalysts for biomass gasification,” Fuel Process. Technol., 73(3), pp. 155-173.

[10] Bulushev, D. A., and Ross, J. R. H., 2011, "Catalysis for conversion of biomass to fuels via pyrolysis and gasification: A review," Catal. Today, 171(1), pp. 1-13.

[11] Tanksale, A., Beltramini, J. N., and Lu, G. M., 2010, “A review of catalytic hydrogen production processes from biomass,” Renew. Sustain. Energy Rev., 14(1), pp. 166-182.

[12] Saxena, R. C., Seal, D., Kumar, S., and Goyal, H. B., 2008, “Thermo-chemical routes for hydrogen rich gas from biomass: A review," Renew. Sustain. Energy Rev., 12(7), pp. 1909-1927.

[13] Puig-Arnavat, M., Bruno, J. C., and Coronas, A., 2010, "Review and analysis of biomass gasification models,” Renew. Sustain. Energy Rev., 14(9), pp. 2841-2851.

[14] Chhiti, Y., and Kemiha, M., 2013, “Thermal Conversion of Biomass , Pyrolysis and Gasification : A Review,” Int. J. Eng. Siences, 2(3), pp. 75-85.

[15] Pereira, E. G., da Silva, J. N., de Oliveira, J. L., and Machado, C. S., 2012, "Sustainable energy: A review of gasification technologies,” Renew. Sustain. Energy Rev., 16(7), pp. 4753-4762. 
[16] Parthasarathy, P., and Narayanan, K. S., 2014, "Hydrogen production from steam gasification of biomass: Influence of process parameters on hydrogen yield - A review," Renew. Energy, 66, pp. 570-579.

[17] Mohan, D., Pittman, C. U., and Steele, P. H., 2006, "Pyrolysis of Wood / Biomass for Biooil : A Critical Review,” Energy \& Fuels, 20(4), pp. 848-889.

[18] McKendry, P., 2002, "Energy production from biomass (part 1): overview of biomass," Bioresour. Technol., 83(1), pp. 37-46.

[19] Wang, L., Weller, C. L., Jones, D. D., and Hanna, M. A., 2008, “Contemporary issues in thermal gasification of biomass and its application to electricity and fuel production," Biomass and Bioenergy, 32(7), pp. 573-581.

[20] Kamińska-Pietrzak, N., and Smoliński, A., 2013, "Selected Environmental Aspects of Gasification and Co-Gasification of Various Types of Waste,” J. Sustain. Min., 12(4), pp. 6-13.

[21] Kim, S.-S., and Agblevor, F. A., 2007, "Pyrolysis characteristics and kinetics of chicken litter.," Waste Manag., 27(1), pp. 135-40.

[22] de Jongejong, W., Di Nola, G., Venneker, B., Spliethoff, H., and Wojtowicz, M., 2007, “TG-FTIR pyrolysis of coal and secondary biomass fuels: Determination of pyrolysis kinetic parameters for main species and NOx precursors," Fuel, 86(15), pp. 2367-2376.

[23] Kim, S.-S., Agblevor, F. A., and Lim, J., 2009, "Fast pyrolysis of chicken litter and turkey litter in a fluidized bed reactor," J. Ind. Eng. Chem., 15(2), pp. 247-252.

[24] Agblevor, F. A., Beis, S., Kim, S. S., Tarrant, R., and Mante, N. O., 2010, "Biocrude oils from the fast pyrolysis of poultry litter and hardwood.," Waste Manag., 30(2), pp. 298- 
307.

[25] Joseph, P., Tretsiakova-McNally, S., and McKenna, S., 2012, “Characterization of cellulosic wastes and gasification products from chicken farms.," Waste Manag., 32(4), pp. 701-709.

[26] Font-Palma, C., 2012, "Characterisation, kinetics and modelling of gasification of poultry manure and litter: An overview,” Energy Convers. Manag., 53(1), pp. 92-98.

[27] Priyadarsan, S., Annamalai, K., Sweeten, J. M., Holtzapple, M. T., and Mukhtar, S., 2005, “Co-gasification of blended coal with feedlot and chicken litter biomass," Proc. Combust. Inst., 30(2), pp. 2973-2980.

[28] Kirubakaran, V., Sivaramakrishnan, V., Premalatha, M., and Subramanian, P., 2007, “Kinetics of Auto-Gasification of Poultry Litter,” Int. J. Green Energy, 4(5), pp. 519-534.

[29] Xiao, X., Le, D. D., Li, L., Meng, X., Cao, J., Morishita, K., and Takarada, T., 2010, "Catalytic steam gasification of biomass in fluidized bed at low temperature: Conversion from livestock manure compost to hydrogen-rich syngas," Biomass and Bioenergy, 34(10), pp. 1505-1512.

[30] Yanagida, T., Minowa, T., Shimizu, Y., Matsumura, Y., and Noda, Y., 2009, "Recovery of activated carbon catalyst, calcium, nitrogen and phosphate from effluent following supercritical water gasification of poultry manure.," Bioresour. Technol., 100(20), pp. $4884-4886$.

[31] Yanagida, T., Minowa, T., Nakamura, A., Matsumura, Y., and Noda, Y., 2008, "Behavior of inorganic elements in poultry manure during supercritical water gasification," Nihon Enerugi Gakkaishi/Journal Japan Inst. Energy., 86, pp. 731-736 
[32] Pinto, F., André, R., Miranda, M., Neves, D., Varela, F., and Santos, J., 2016, "Effect of gasification agent on co-gasification of rice production wastes mixtures," Fuel, 180, pp. $407-416$.

[33] Mahinpey, N., and Gomez, A., 2016, "Review of gasification fundamentals and new findings: Reactors, feedstock, and kinetic studies,” Chem. Eng. Sci., 148, pp. 14-31.

[34] Karatas, H., Olgun, H., and Akgun, F., 2012, "Experimental results of gasification of waste tire with air\&amp;CO2, air\&amp;steam and steam in a bubbling fluidized bed gasifier," Fuel Process. Technol., 102, pp. 166-174.

[35] Ahmed, I., and Gupta, A. K., 2011, "Kinetics of woodchips char gasification with steam and carbon dioxide,” Appl. Energy, 88(5), pp. 1613-1619.

[36] Marquez-Montesinos, F., Cordero, T., Rodríguez-Mirasol, J., and Rodríguez, J. J., 2002, “CO2 and steam gasification of a grapefruit skin char," Fuel, 81(4), pp. 423-429.

[37] Ahmed, I., and Gupta, A. K., 2009, "Syngas yield during pyrolysis and steam gasification of paper," Appl. Energy, 86(9), pp. 1813-1821.

[38] Hussein, M. S., 2016, "Experimental Investigation of Chicken Manure Pyrolysis and Gasification," PhD Dissertation, University of Wisconsin-Milwaukee, WI.

[39] Ahmed, I., and Gupta, A. K., 2012, "Sugarcane bagasse gasification: Global reaction mechanism of syngas evolution,” Appl. Energy, 91(1), pp. 75-81.

[40] Nipattummakul, N., Ahmed, I., Kerdsuwan, S., and Gupta, A. K., 2010, "High temperature steam gasification of wastewater sludge,” Appl. Energy, 87(12), pp. 37293734.

[41] Burra, K. G., Hussein, M. S., Amano, R. S., and Gupta, A. K., 2016, “Syngas evolutionary 
behavior during chicken manure pyrolysis and air gasification,” Appl. Energy, 181, pp. $408-415$.

[42] Hussein, M. S., Burra, K. G., Amano, R. S., and Gupta, A. K., 2017, “Effect of oxygen addition in steam gasification of chicken manure," Fuel, 189, pp. 428-435.

[43] "Phyllis2, database for biomass and waste," 2015, [Online]. Available at: https://www.ecn.nl/phyllis2/Biomass/View/3501. 
Table 1. Proximate and ultimate analysis of chicken manure [43]

\begin{tabular}{|l|l|}
\hline Proximate Analysis (wt. \% dry) & \\
\hline Volatile content & 65.56 \\
\hline Ash content at $550{ }^{\circ} \mathrm{C}$ & 21.65 \\
\hline Fixed carbon & 12.8 \\
\hline Ultimate Analysis (wt. \% dry) & \\
\hline Carbon & \\
\hline Hydrogen & 35.59 \\
\hline Nitrogen & 4.57 \\
\hline Sulfur & \\
\hline Oxygen & 13.15 \\
\hline HHV (in MJ/kg) & \\
\hline
\end{tabular}




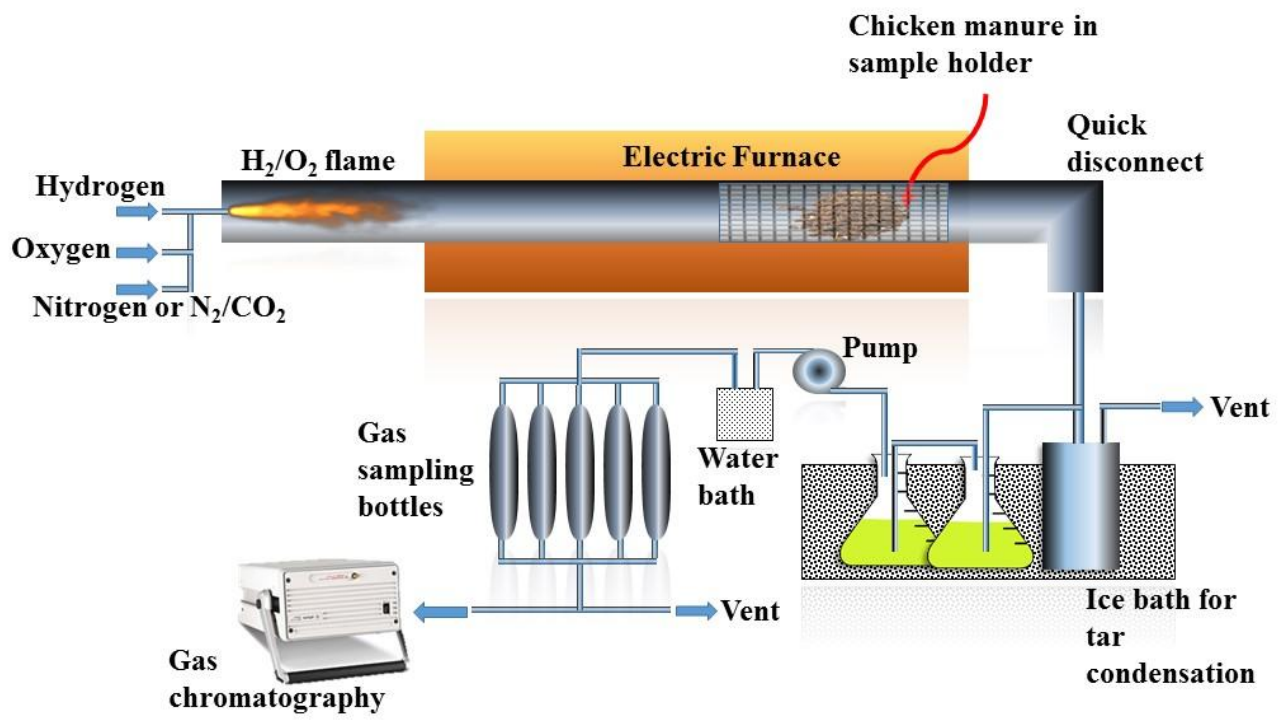

Figure 1. Schematic diagram of the lab-scale semi-batch reactor 


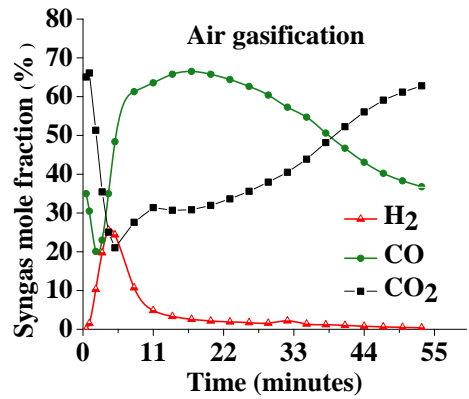

(a)

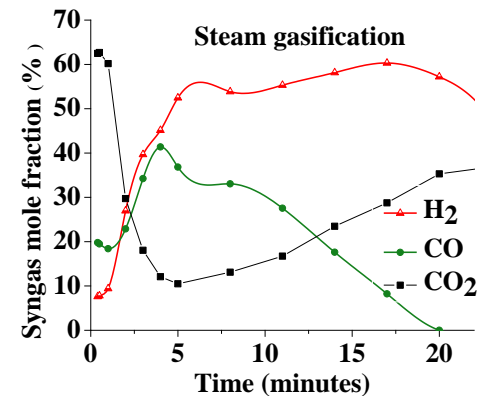

(b)

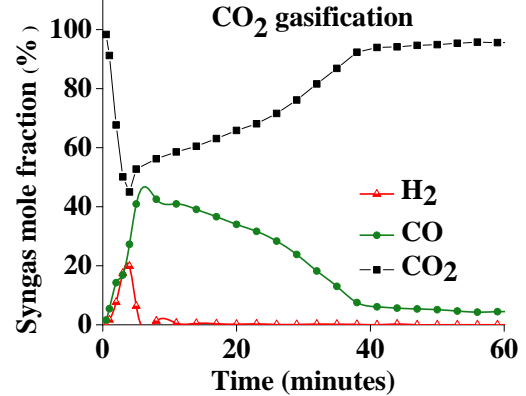

(c)

Figure 2. Syngas dry mole fraction (without $\mathrm{N}_{2}$ and $\mathrm{O}_{2}$ ) evolution for different gasifying agents at $1000{ }^{\circ} \mathrm{C}$ 


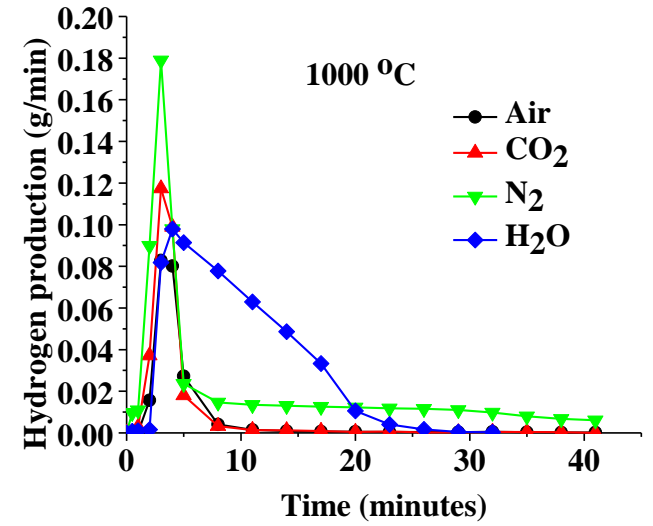

(a)

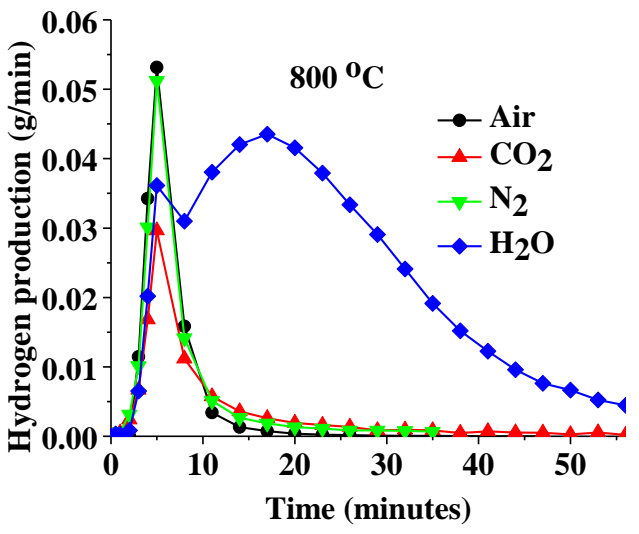

(c)

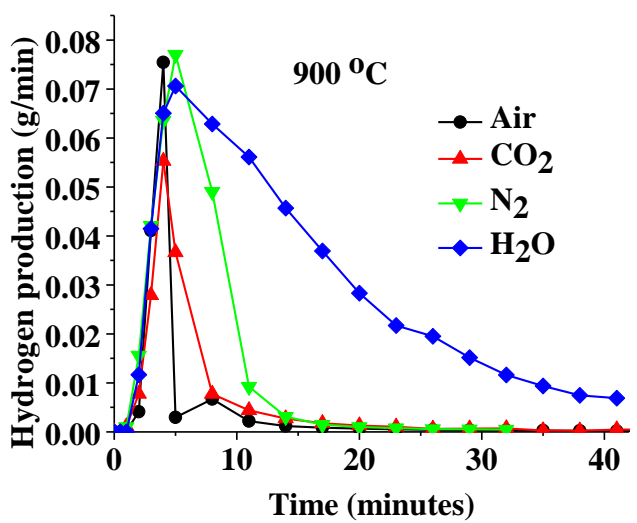

(b)

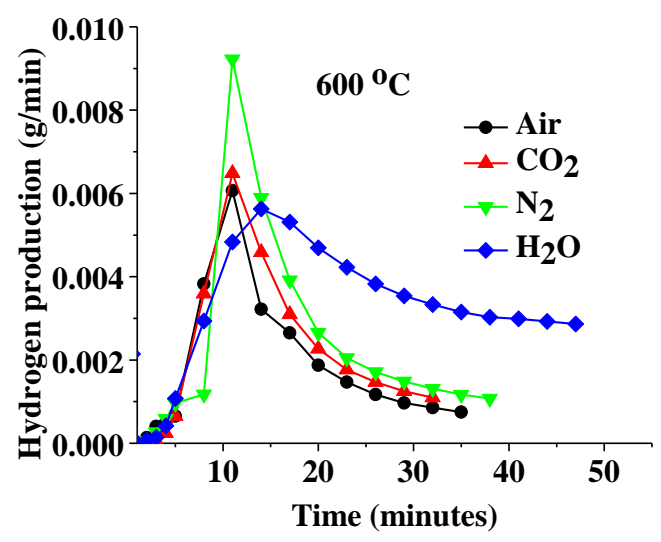

(d)

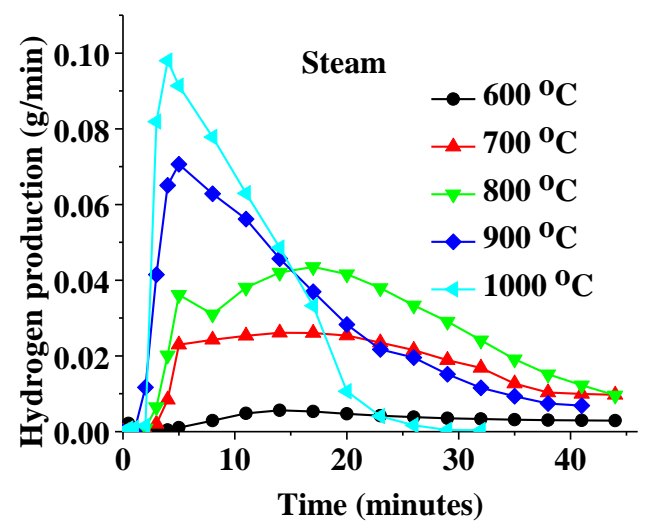

(e)

Figure 3. Evolutionary behavior of hydrogen yield for different gasifying media at different temperatures 


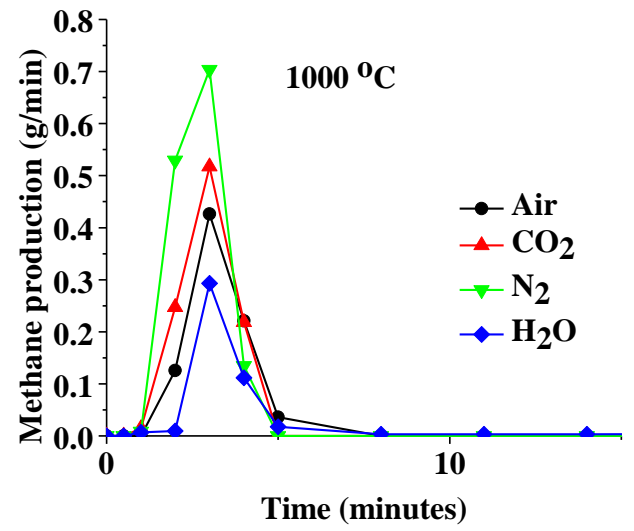

(a)

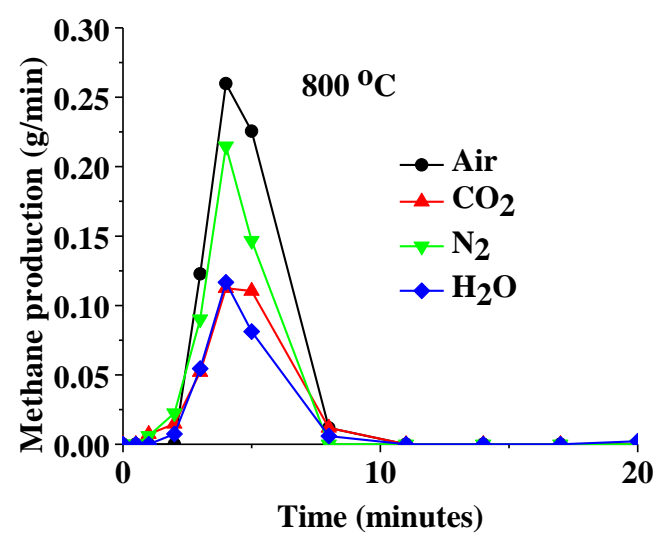

(c)

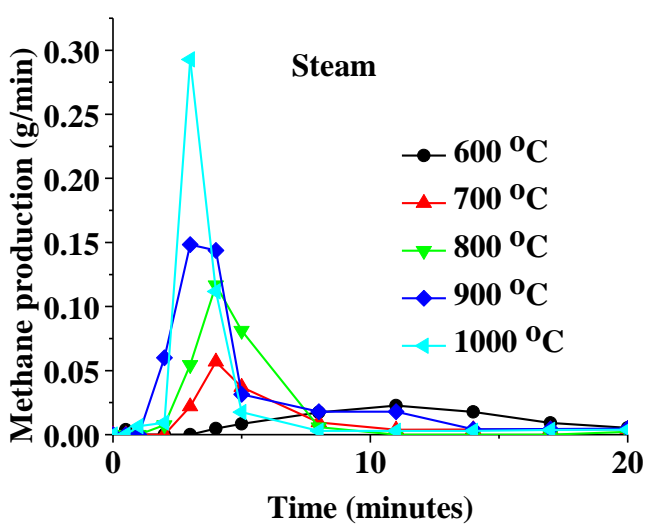

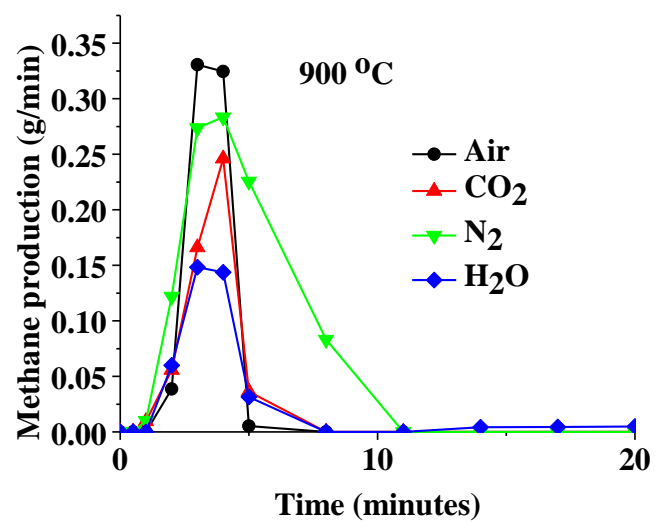

(b)

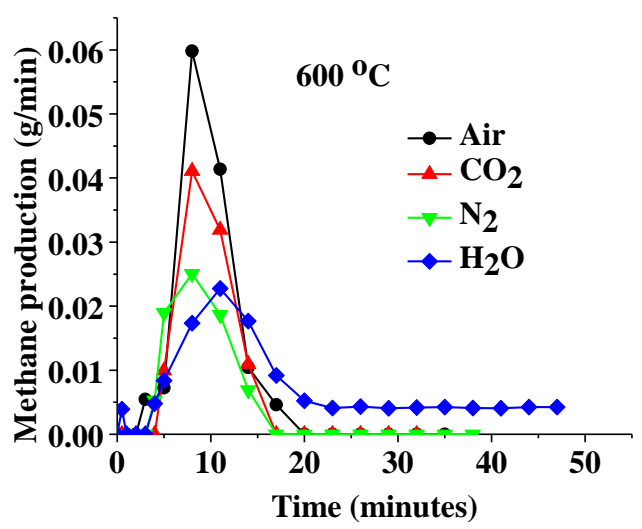

(d)

(e)

Figure 4. Evolutionary behavior of methane yield for different gasifying media at different temperatures 


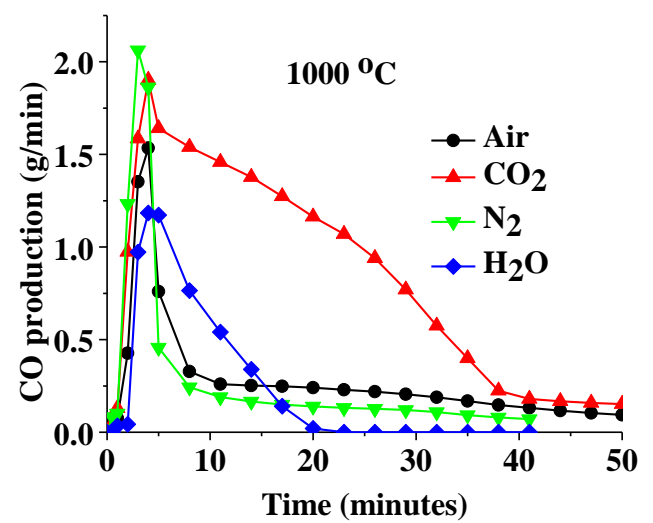

(a)

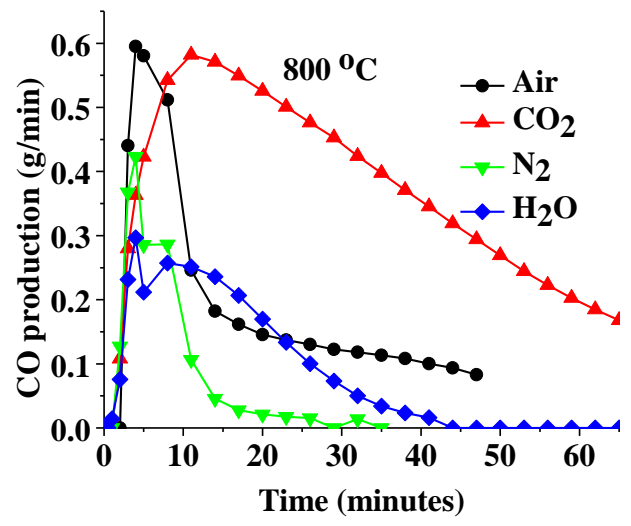

(c)

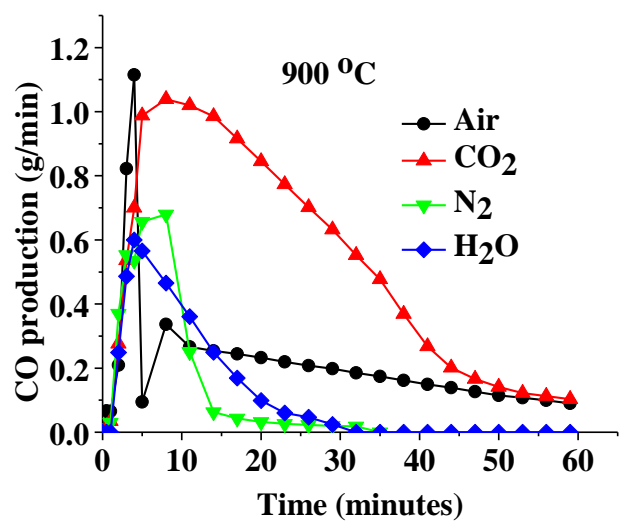

(b)

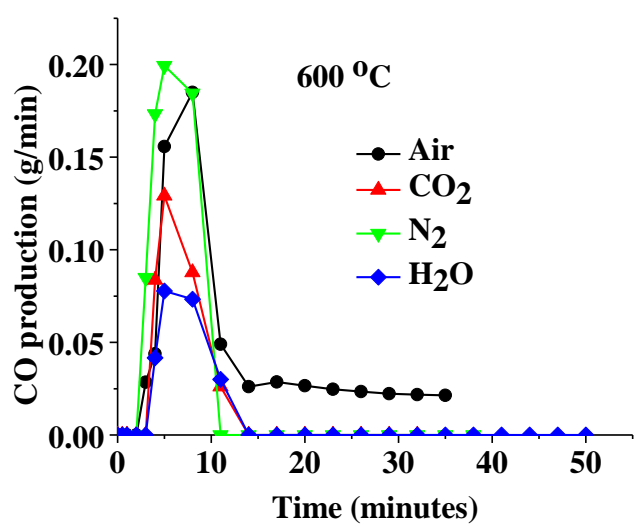

(d)

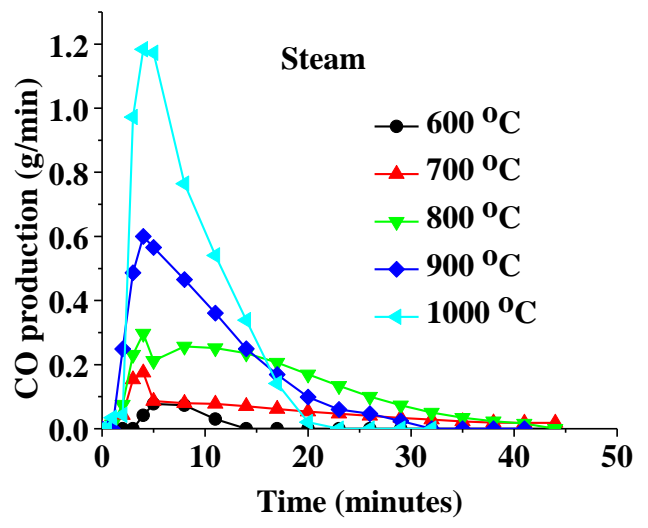

(e)

Figure 5. Evolutionary behavior of carbon monoxide yield for different gasifying media at different temperatures 


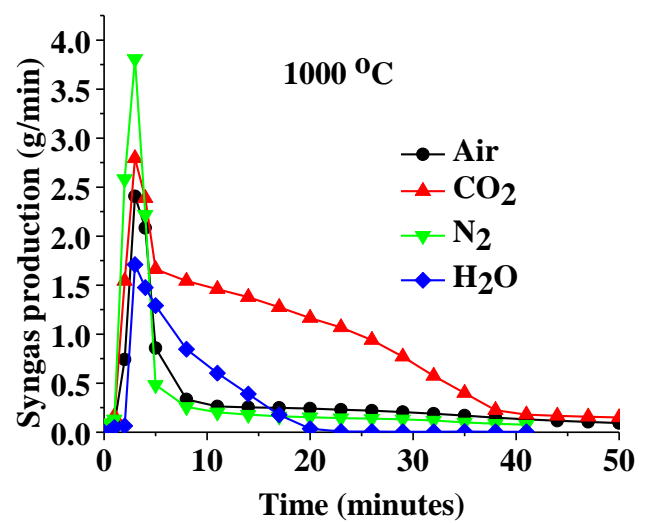

(a)

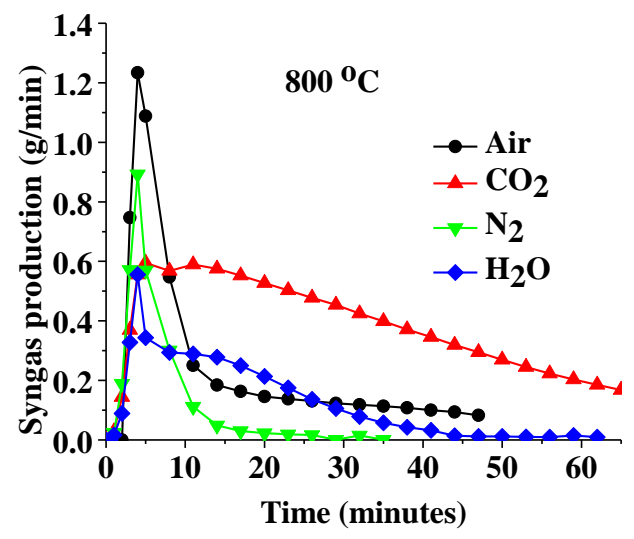

(c)

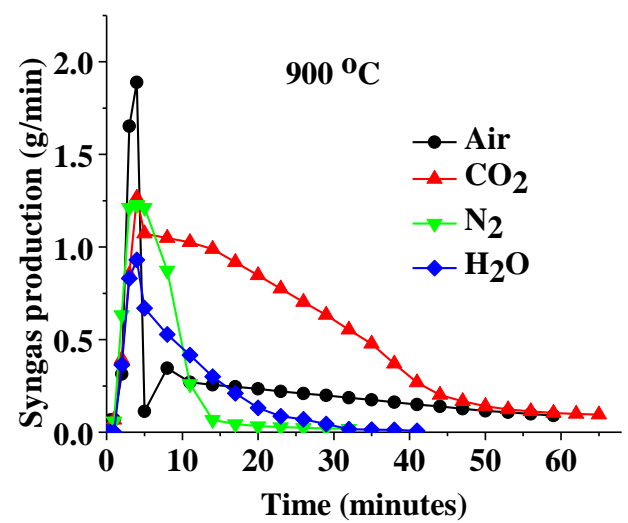

(b)

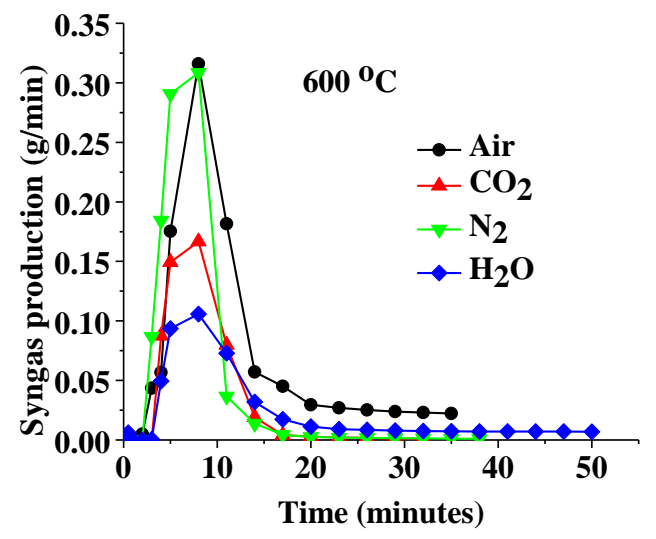

(d)

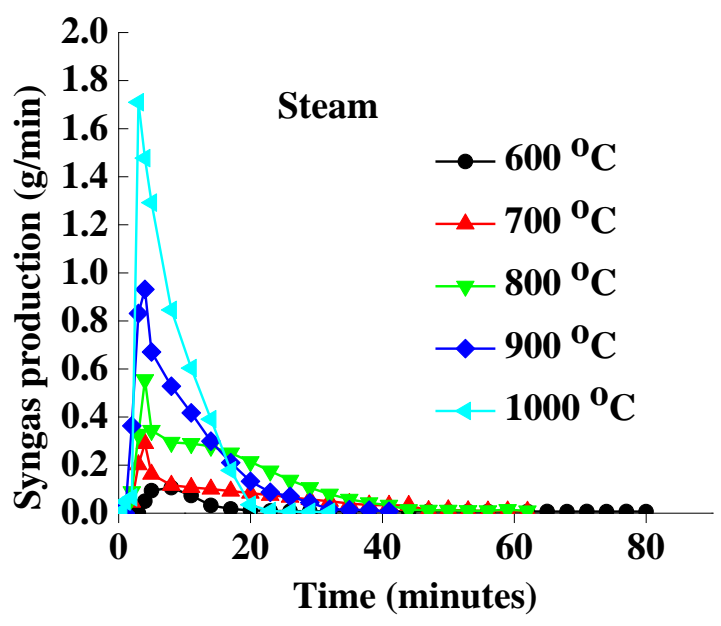

(e)

Figure 6. Evolutionary behavior of syngas yield for different gasifying media at different temperatures 


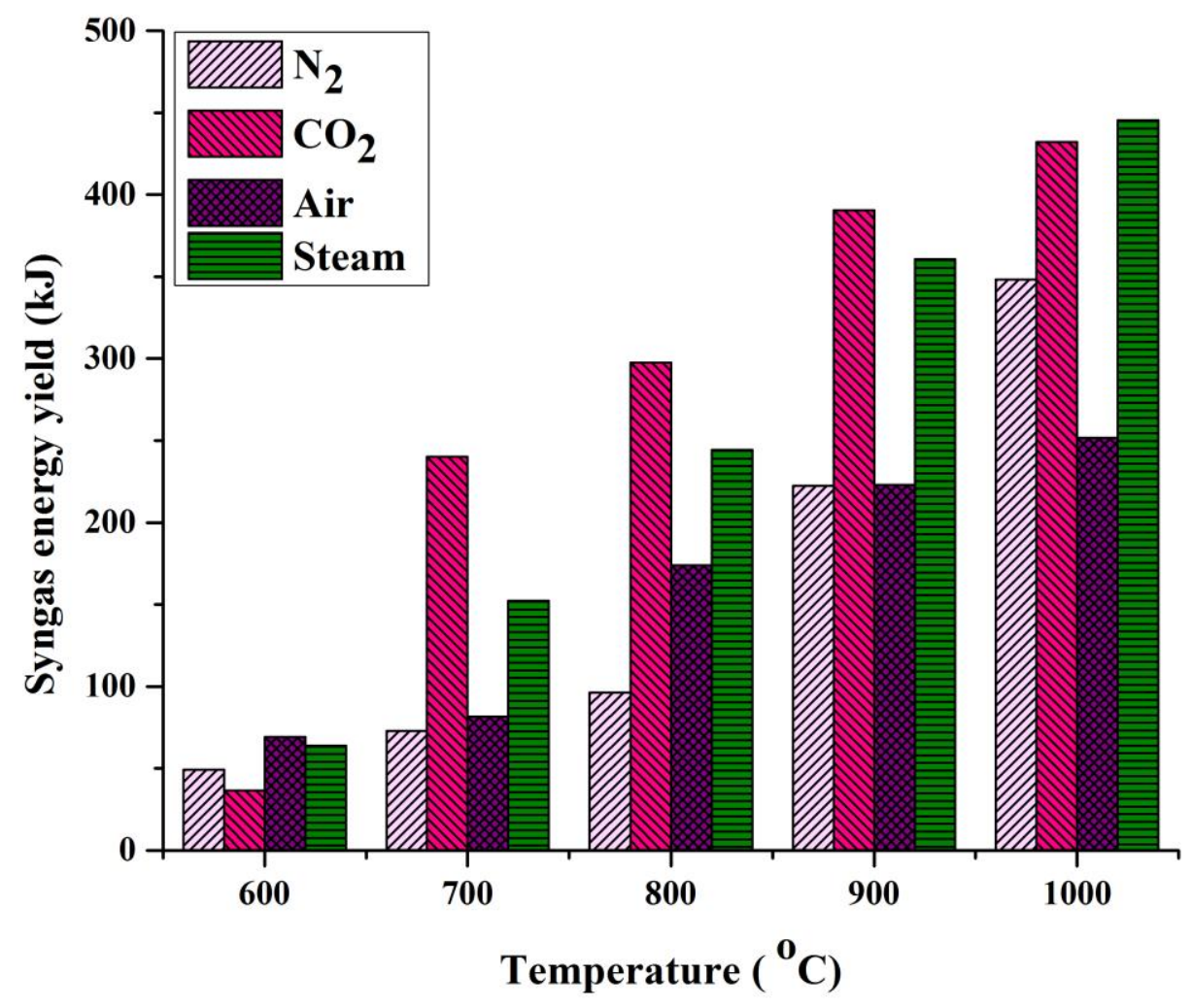

Figure 7. Cumulative energy output for different temperature and different gasifying agents 
Figure 8

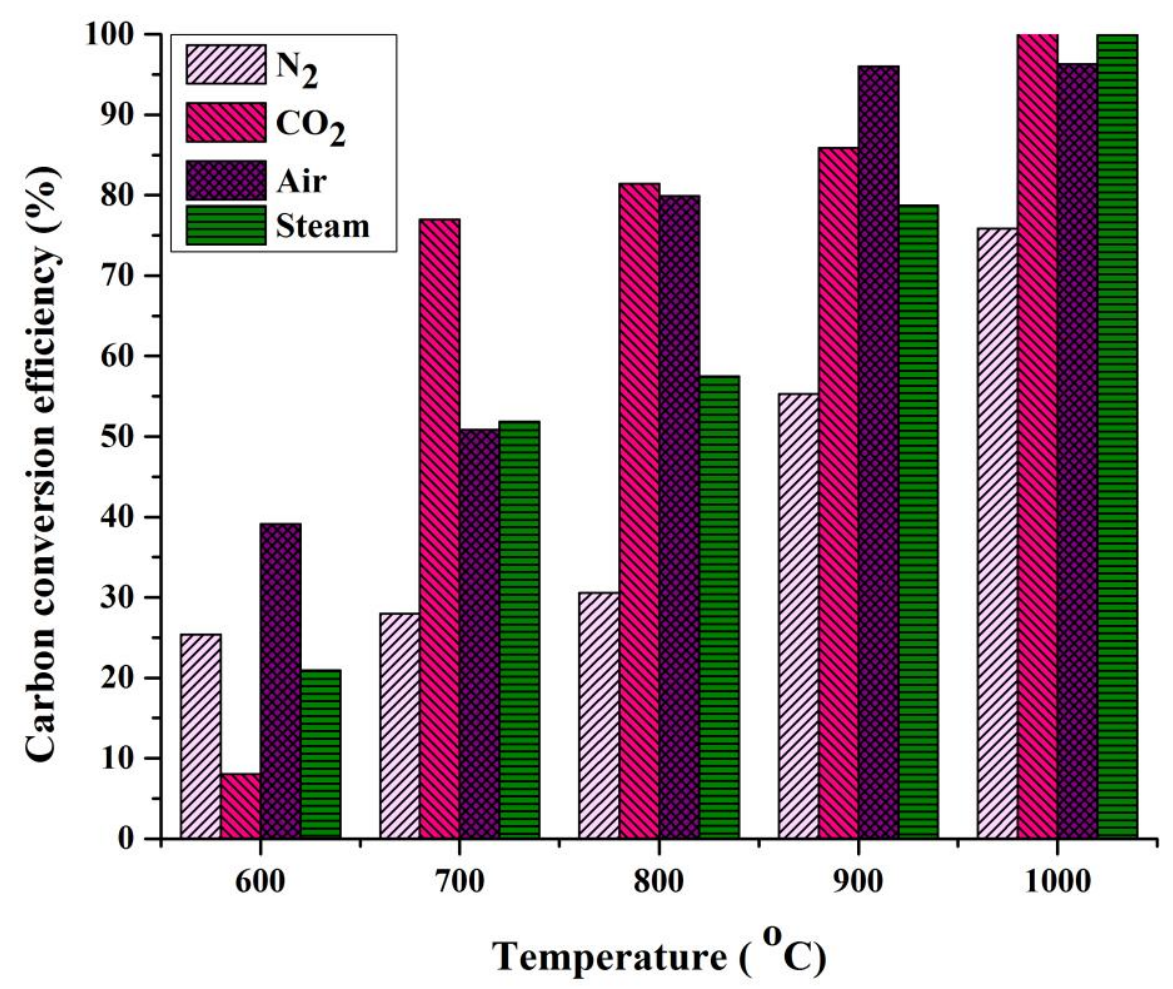

Figure 8. Carbon conversion efficiency for different temperature and different gasifying agents 